Article

\title{
An Iron-Based Catalyst with Multiple Active Components Synergetically Improved Electrochemical Performance for Oxygen Reduction Reaction
}

\author{
Jian Zhang ${ }^{1,+}\left(\mathbb{D}\right.$, Xiaoming Song ${ }^{2,+}$, Ping $\mathrm{Li}^{3}$, Shuai Wang ${ }^{3, *}$, Zexing $\mathrm{Wu}^{3, *}$ and Xien $\mathrm{Liu}^{3, *} \mathbb{C}$ \\ 1 College of Chemical Engineering, Qingdao University of Science \& Technology, Qingdao 266042, China; \\ jian8552@163.com \\ 2 College of Marine Science and Biological Engineering, Qingdao University of Science \& Technology, \\ Qingdao 266042, China; ss4007@sina.com \\ 3 State Key Laboratory Base of Eco-chemical Engineering, College of Chemistry and Molecular Engineering, \\ Qingdao University of Science \& Technology, Qingdao 266042, China; qustlipingest@163 \\ * Correspondence: qustwangshuai@qust.edu.cn (S.W.); splswzx@qust.edu.cn (Z.W.); \\ liuxien@qust.edu.cn (X.L.); Tel.: +86-150-9202-5911 (S.W.); +86-187-6390-9193 (Z.W.); +86-139-6968-0591 (X.L.) \\ $\dagger$ These authors contributed equally to this work.
}

Received: 18 May 2018; Accepted: 4 June 2018; Published: 7 June 2018

\begin{abstract}
Lack of highly active and stable non-precious metal catalysts (NPMCs) as an alternative to $\mathrm{Pt}$ for oxygen reduction reaction (ORR) in the application of zinc-air batteries and proton-exchange membrane fuel cells (PEMFCs) significantly hinders the commercialization of these energy devices. Herein, we synthesize a new type of catalyst composed of nitrogen-coordinated and carbon-embedded metal $\left(\mathrm{Fe}-\mathrm{N} / \mathrm{Fe}_{3} \mathrm{C} / \mathrm{Fe} / \mathrm{C}\right)$ by pyrolyzing a precursor at $800{ }^{\circ} \mathrm{C}$ under argon atmosphere, and the precursor is obtained by heating a mixture of the tri (dipyrido $\left[3,2-a: 2^{\prime}, 3^{\prime}-c\right]$ phenazinyl) phenylene and $\mathrm{FeSO}_{4}$ at $160{ }^{\circ} \mathrm{C}$ in a Teflon-lined stainless autoclave. The resultant $\mathrm{Fe}-\mathrm{N} / \mathrm{Fe}_{3} \mathrm{C} / \mathrm{Fe} / \mathrm{C}-800$ exhibits the highest activity for the ORR with onset and half-wave potentials of 1.00 and $0.82 \mathrm{~V}$ in $0.1 \mathrm{M} \mathrm{KOH}$, respectively. Furthermore, it also shows a potential ORR activity in $0.1 \mathrm{M} \mathrm{HClO}_{4}$, which is promising for the application in commercial PEMFCs. Most importantly, $\mathrm{Fe}-\mathrm{N} / \mathrm{Fe}_{3} \mathrm{C} / \mathrm{Fe} / \mathrm{C}-800$ exhibits a comparable electrochemical performance to $\mathrm{Pt} / \mathrm{C}$ for the application in zinc-air battery. The specific capacity approaches $700 \mathrm{mAh} \cdot \mathrm{g}^{-1}$, and the maximum power density is also comparable to that of $\mathrm{Pt} / \mathrm{C}$ at the current density of $200 \mathrm{~mA} \cdot \mathrm{cm}^{-2}$. The work opens up a simple strategy to prepare ORR electrocatalyts for zinc-air battery and PEMFCs.
\end{abstract}

Keywords: electrocatalysts; oxygen reduction reaction; iron-nitrogen coordination; iron nanoparticles

\section{Introduction}

Exploring highly active and stable non-precious metal catalysts (NPMCs) as an alternative to $\mathrm{Pt}$ for oxygen reduction reaction (ORR) is crucial to battery devices, such as zinc-air batteries and proton exchange membrane fuel cells (PEMFCs) [1-6]. At present, the Fe-N/C catalysts have been widely considered as the most potential candidates among NPMCs because of their high activity and durability [7-9]. They are mainly prepared by pyrolysis from the mixture of iron salt and nitrogen-containing carbon species [2,10]. In general, the $\mathrm{Fe}-\mathrm{N}_{x}$ are assumed to be catalytically active sites in these catalysts [11]. However, some argued that Fe species only promotes the formation of $\mathrm{N}$-doped carbon, and these nitrogen-doped nanomaterials are catalytically active [12-17]. In addition, iron particles and/or iron carbides are often formed in preparing the $\mathrm{Fe}-\mathrm{N}_{x}$ catalysts during the 
pyrolyzing process at high temperatures, which can hardly be completely removed by the pickling [18]. Their role in Fe-N/C catalysts for ORR is quite difficult to be ruled out without the support of in situ techniques. Recently, Deng et al. reported that carbon nanotube-embedded (CNT-embedded) iron nanoparticles were highly active for ORR in acidic media [19]. Yang et al. synthesized CNT/ $\mathrm{Fe}_{3} \mathrm{C}$ nanoparticle hybrids that exhibited high performances in both alkaline and acidic environments [20]. Although the active sites of $\mathrm{Fe}-\mathrm{N} / \mathrm{C}$ catalysts remain debate, a large number of researches have indicated that $\mathrm{Fe}$ species, nitrogen-containing carbon materials and pyrolysis temperatures are critical parameters influencing the performance of Fe-N/C catalysts [21]. Nevertheless, the mentioned synthetic method often leads to uncontrollable agglomeration and inhomogeneous microstructures of metal nanoparticles in these catalysts [22]. To address the bottleneck, template [23,24] and template-free $[25,26]$ synthesis of NPMCs have been developed. In particular, Müllen and Dai's groups synthesized high-performance electrocatalysts by pyrolysis of self-supporting porphyrin-based polymer frameworks $[27,28]$. In these catalysts, metal nanoparticles are uniformly distributed and embedded in nitrogen-rich carbon.

Herein, we prepared a highly effective ORR electrocatalyst formed by nitrogen-coordinated and carbon-embedded metal $\left(\mathrm{Fe}-\mathrm{N} / \mathrm{Fe}_{3} \mathrm{C} / \mathrm{Fe} / \mathrm{C}\right)$ via the template-free pyrolysis of tri (dipyrido $\left[3,2-a: 2^{\prime}, 3^{\prime}-c\right]$ phenazinyl) phenylene-based metal organic framework (MOF). $\mathrm{Fe}-\mathrm{N} / \mathrm{Fe}_{3} \mathrm{C} / \mathrm{Fe} / \mathrm{C}-800$ exhibited the excellent activity and durability for ORR, evidenced by a very similar onset potential to $\mathrm{Pt} / \mathrm{C}$ in acidic and alkali corrosive media, as well as a comparable half-wave potential of $0.82 \mathrm{~V}$ to $\mathrm{Pt} / \mathrm{C}$ in a $0.1 \mathrm{M} \mathrm{KOH}$ solution. Meanwhile, $\mathrm{Fe}-\mathrm{N} / \mathrm{Fe}_{3} \mathrm{C} / \mathrm{Fe} / \mathrm{C}-800$ showed a good stability and excellent methanol tolerance in both alkaline and acidic environments. The half-wave potentials were only negatively shifted by 23.3 and $20.2 \mathrm{mV}$ after 3000 cycles in alkaline and acidic electrolytes, respectively, while there were insignificant changes observed between the cyclic voltammetry (CV) curves taken in methanol and without methanol in both electrolytes.

\section{Results and Discussion}

We synthesized $\mathrm{Fe}-\mathrm{N} / \mathrm{Fe}_{3} \mathrm{C} / \mathrm{Fe} / \mathrm{C}-800$ by the pyrolysis of the metal organic framework at $800{ }^{\circ} \mathrm{C}$ under the argon for $1.5 \mathrm{~h}$ (Scheme 1). The synthesis details were provided in the experimental section. Figure 1a shows an SEM image of $\mathrm{Fe}-\mathrm{N} / \mathrm{Fe}_{3} \mathrm{C} / \mathrm{Fe} / \mathrm{C}-800$ with a disordered carbon morphological feature. The HRTEM images of $\mathrm{Fe}-\mathrm{N} / \mathrm{Fe}_{3} \mathrm{C} / \mathrm{Fe} / \mathrm{C}-800$ were mainly amorphous. Metal nanoparticles with a diameter of $\sim 30 \mathrm{~nm}$ were decorated on carbon and covered with graphitic carbon shells $(\sim 5 \mathrm{~nm})$ (Figure 1b). The elemental composition of the catalyst was analyzed by using HAADF-STEM-EDS STEM images (Figure 1c-h). The metal nanoparticles were identified as $\mathrm{Fe}$ or $\mathrm{Fe}_{3} \mathrm{C}$ embedded in graphitic carbon, instead of FeS. However, the TEM images showed an unclear crystal lattice, which was difficult to distinguish carbon-embedded $\mathrm{Fe}$ from $\mathrm{Fe}_{3} \mathrm{C}$ nanoparticles. HAADF-STEM-EDS images indicated that $\mathrm{Fe}, \mathrm{N}$ and $\mathrm{S}$ were uniformly distributed on the carbon matrix except $\mathrm{Fe}$ and $\mathrm{Fe}_{3} \mathrm{C}$ sections. The elemental $\mathrm{S}$ was from the starting reactant, $\mathrm{FeSO}_{4}$. Figure $2 \mathrm{a}$ compares the XRD patterns of $\mathrm{Fe}-\mathrm{N} / \mathrm{Fe}_{3} \mathrm{C} / \mathrm{Fe} / \mathrm{C}-800$, Ligand- 800 and S-ligand-800. A broad diffraction peak at 25.4 assigned to the (002) planes of graphitic carbon and a peak observed at $44.8^{\circ}$ in $\mathrm{Fe}-\mathrm{N} / \mathrm{Fe}_{3} \mathrm{C} / \mathrm{Fe} / \mathrm{C}-800$ indicated the presence of $\alpha$-Fe (JCPDS, 87-0722) [29]. The peaks at $43.6^{\circ}$ and $50.5^{\circ}$ were assigned to the crystalline planes of $\mathrm{Fe}_{3} \mathrm{C}$ species (JCPDS, 89-2867) [30]. The results of XRD indicated that the catalyst contained both $\mathrm{Fe}$ and $\mathrm{Fe}_{3} \mathrm{C}$ nanoparticles. To further provide insight into the structure of $\mathrm{Fe}-\mathrm{N} / \mathrm{Fe}_{3} \mathrm{C} / \mathrm{Fe} / \mathrm{C}-800$, its surface compositions were further examined by XPS, XANES and EXAFS. The full XPS spectra of the catalyst were recorded in Figure $2 \mathrm{~b}$. All elements, including $\mathrm{C}, \mathrm{O}, \mathrm{N}, \mathrm{S}$ and $\mathrm{Fe}$, were detected. The percentages of the elemental C, N, O, S and Fe were approximately 85.05, 6.65, 5.59, 2.21 and 0.51\% in weight, respectively. Four dominant nitrogen peaks at 398.2, 399.4, 400.9, and $402.1 \mathrm{eV}$ corresponded to pyridinic $(25.10 \%)$, pyrrolic $(24.93 \%)$, graphitic $(25.19 \%)$ and quarternary $(24.78 \%)$, respectively (Figure 2c). The pyridinic and pyrrolic $\mathrm{N}$ were regarded as ORR active reagents because they are capable of coordinating with transition metal by lone-pair electrons [31,32]. Graphitic nitrogen was also reported to be important for ORR. Recently, density functional theory (DFT) calculation announced 
that existence of quaternary $\mathrm{N}$ in graphene structures significantly enhanced the catalytic activity of carbon, because of a non-uniform electron distribution. These forms of nitrogen with high content were beneficial to create the highly active catalysts. In the Fe2p spectrum, the peaks at 710.1 and $713.6 \mathrm{eV}$ were assigned to the binding energies of the $2 \mathrm{p}_{3 / 2}$ orbitals of $\mathrm{Fe}^{2+}$ and $\mathrm{Fe}^{3+}$ species, respectively (Figure 2d) [33]. The peaks at 722.9 and $727.5 \mathrm{eV}$ were attributed to the binding energies of the $2 \mathrm{p}_{1 / 2}$ orbitals of $\mathrm{Fe}^{2+}$ and $\mathrm{Fe}^{3+}$ species. The satellite peak was also observed at $717.2 \mathrm{eV}$. The XANES and EXAFS for Fe K-edge of $\mathrm{Fe}-\mathrm{N} / \mathrm{Fe}_{3} \mathrm{C} / \mathrm{Fe} / \mathrm{C}-800$ and references are shown in Figure 2e,f. The reference Fe phthalocyanine had a pre-edge peak at $7118 \mathrm{eV}$ that was assigned to a $1 \mathrm{~s} \rightarrow 4 \mathrm{pz}$ shakedown transition characteristic for a square-planar D4h symmetry. The pre-edge feature was not observed in $\mathrm{Fe}-\mathrm{N} / \mathrm{Fe}_{3} \mathrm{C} / \mathrm{Fe} / \mathrm{C}-800$ that revealed a different local environment of $\mathrm{Fe}-\mathrm{N}_{x}$, such as a distorted square planer (D2h). The shoulder at $7112 \mathrm{eV}$ in the spectrum of $\mathrm{Fe}-\mathrm{N} / \mathrm{Fe}_{3} \mathrm{C} / \mathrm{Fe} / \mathrm{C}-800$ was the feature of metallic Fe species (Figure 2e). There were two dominant peaks for $\mathrm{Fe}-\mathrm{N} / \mathrm{Fe}_{3} \mathrm{C} / \mathrm{Fe} / \mathrm{C}-800$ in EXAFS. The characteristic peak at $1.6 \AA$ indicated an Fe-N interaction, and the peak at $2.2 \AA$ coincided with $\mathrm{Fe}-\mathrm{Fe}$ scattering of metallic $\mathrm{Fe}$ and $\mathrm{Fe}_{3} \mathrm{C}$ standards (Figure 2f) [34]. We also compared the EXAFS of $\mathrm{Fe}-\mathrm{N} / \mathrm{Fe}_{3} \mathrm{C} / \mathrm{Fe} / \mathrm{C}-800$ with $\mathrm{Fe}$ phthalocyanine and metallic Fe. The characteristic peaks of the $\mathrm{Fe}-\mathrm{N}$ and $\mathrm{Fe}-\mathrm{Fe}$ interactions in these references were slightly different from $\mathrm{Fe}-\mathrm{N} / \mathrm{Fe}_{3} \mathrm{C} / \mathrm{Fe} / \mathrm{C}-800$. This is because $\mathrm{Fe}$ and $\mathrm{Fe}_{3} \mathrm{C}$ in $\mathrm{Fe}-\mathrm{N} / \mathrm{Fe}_{3} \mathrm{C} / \mathrm{Fe} / \mathrm{C}-800$ were embedded in carbon, and the Fe-N bonding symmetry in the catalyst was not square-planar (D4h)-like in the Fe phthalocyanine. Thus, taking all of these analysis, including SEM, TEM, XRD, XPS, XANES and EXAFS data together, Fe-N, carbon embedded $\mathrm{Fe}_{3} \mathrm{C}$ and $\mathrm{Fe}$ nanoparticles were identified as the components of the catalyst that were distributed in the N, $\mathrm{S}$ co-doped amorphous carbon.

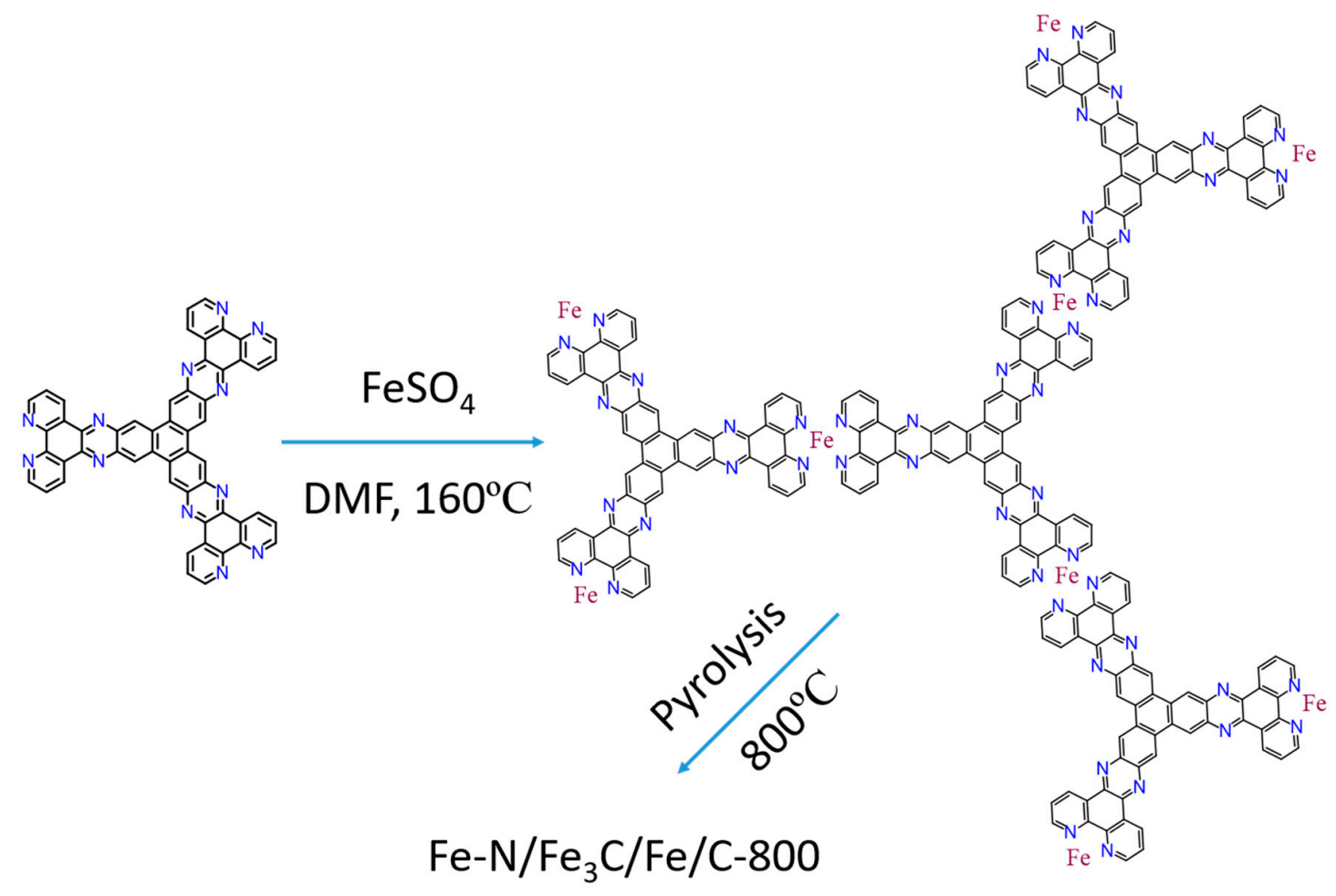

Scheme 1. The illustration of the synthesis for $\mathrm{Fe}-\mathrm{N} / \mathrm{Fe}_{3} \mathrm{C} / \mathrm{Fe} / \mathrm{C}-800$. 


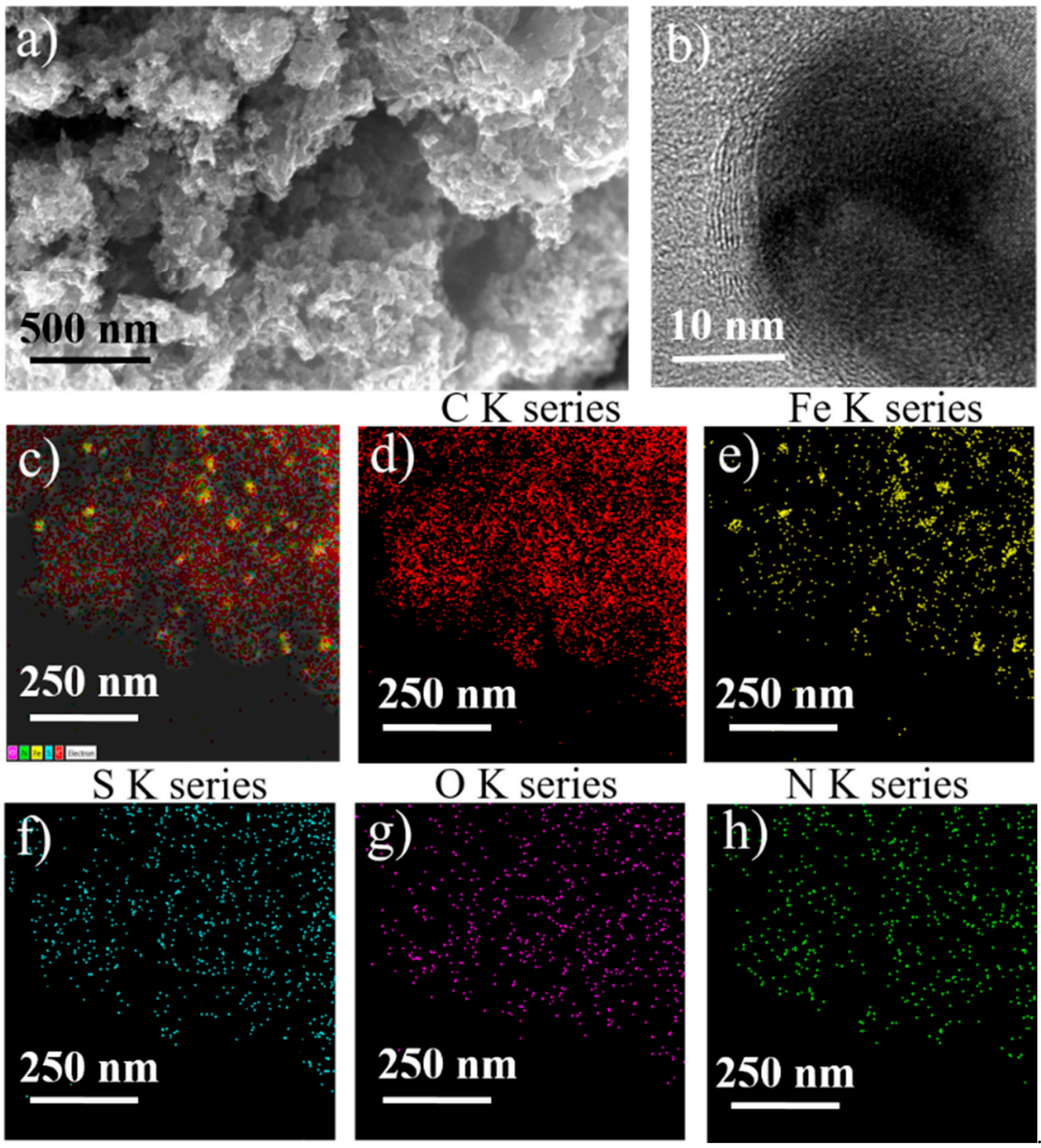

Figure 1. (a) Scanning electron microscopy image of $\mathrm{Fe}-\mathrm{N} / \mathrm{Fe}_{3} \mathrm{C} / \mathrm{Fe} / \mathrm{C}-800$; (b) high-magnification TEM images of $\mathrm{Fe}-\mathrm{N} / \mathrm{Fe}_{3} \mathrm{C} / \mathrm{Fe} / \mathrm{C}-800$; (c-h) HAADF-STEM-EDS images of $\mathrm{Fe}-\mathrm{N} / \mathrm{Fe}_{3} \mathrm{C} / \mathrm{Fe} / \mathrm{C}-800$. 

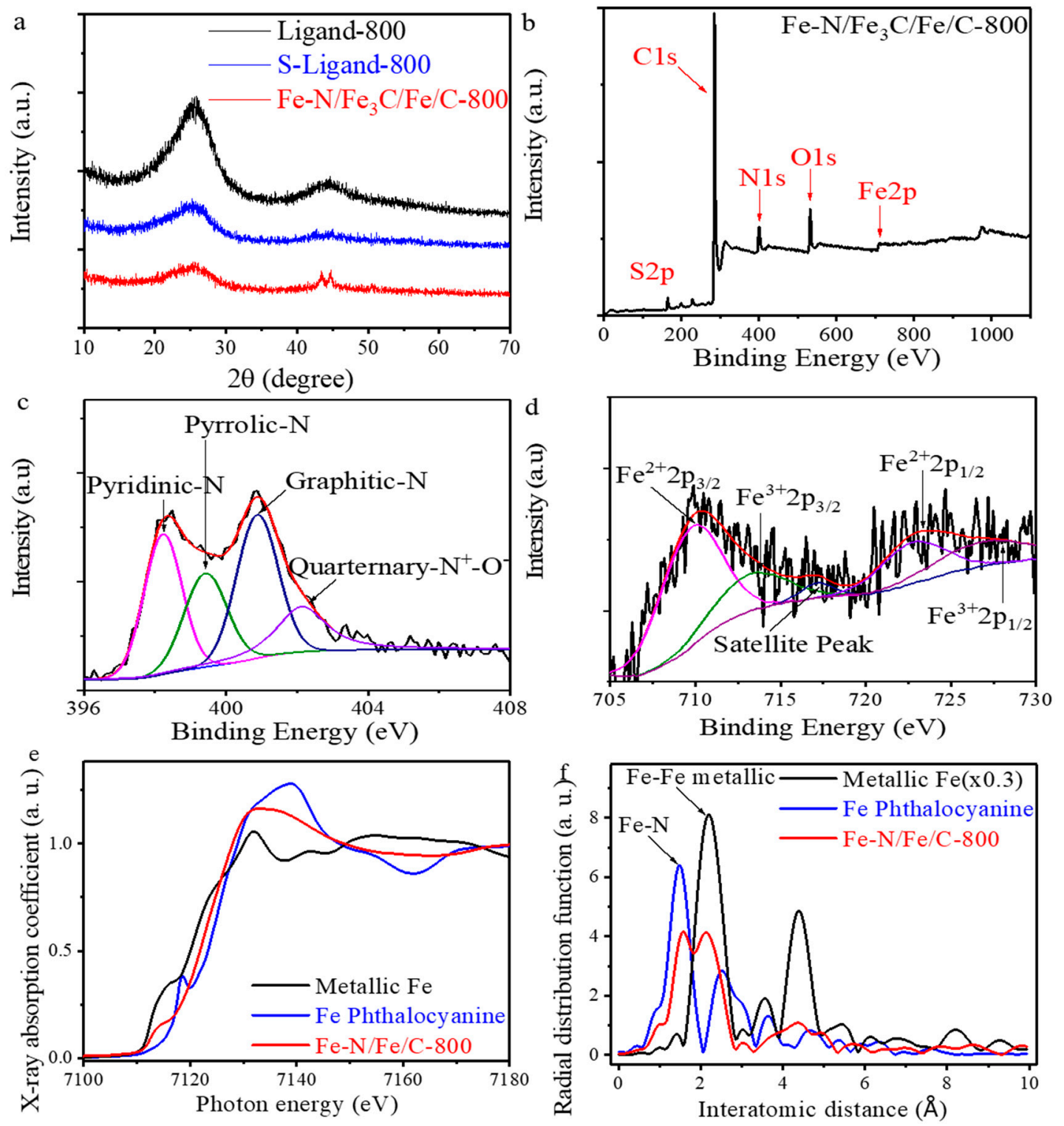

Figure 2. (a) XRD spectra of Ligand-800, S-Ligand-800 and $\mathrm{Fe}-\mathrm{N} / \mathrm{Fe}_{3} \mathrm{C} / \mathrm{Fe} / \mathrm{C}-800$; (b) full XPS spectrum of $\mathrm{Fe}-\mathrm{N} / \mathrm{Fe}_{3} \mathrm{C} / \mathrm{Fe} / \mathrm{C}-800$; (c) XPS spectra of $\mathrm{Fe} 2 \mathrm{p}$ for $\mathrm{Fe}-\mathrm{N} / \mathrm{Fe}_{3} \mathrm{C} / \mathrm{Fe} / \mathrm{C}-800$ in the range of 705 to $730 \mathrm{eV}$; (d) XPS spectra of N1s for Fe-N/Fe 3 C/Fe/C-800; (e) XANES spectra for Fe K-edge of $\mathrm{Fe}-\mathrm{N} / \mathrm{Fe}_{3} \mathrm{C} / \mathrm{Fe} / \mathrm{C}-800$ and references; and (f) EXAFS spectra for $\mathrm{Fe} \mathrm{K}-$ edge of $\mathrm{Fe}-\mathrm{N} / \mathrm{Fe}_{3} \mathrm{C} / \mathrm{Fe} / \mathrm{C}-800$ and references.

The catalytic activities of $\mathrm{Fe}-\mathrm{N} / \mathrm{Fe}_{3} \mathrm{C} / \mathrm{Fe} / \mathrm{C}-800$ and $\mathrm{Pt} / \mathrm{C}$ catalysts for ORR were investigated by cyclic voltammetry (CV) and LSV measurements in $\mathrm{O}_{2}$ - or $\mathrm{N}_{2}$-saturated $0.1 \mathrm{M} \mathrm{KOH}$ and $0.1 \mathrm{M} \mathrm{HClO}_{4}$ ((Figure 3). Fe-N/Fe $3 \mathrm{C} / \mathrm{Fe} / \mathrm{C}-800$ exhibited a quasi-rectangular double-layer capacity current in $\mathrm{N}_{2}$ saturated $0.1 \mathrm{M} \mathrm{KOH}$ solution (Figure $3 \mathrm{a}$ ). Its ORR peak potential was located at $0.79 \mathrm{~V}$ in $\mathrm{O}_{2}$ saturated $0.1 \mathrm{M} \mathrm{KOH}$ solution, which was negatively shifted by $0.07 \mathrm{~V}$ relative to $\mathrm{Pt} / \mathrm{C}$. However, its peak current $(106.5 \mu \mathrm{A})$ was much higher than that of $\mathrm{Pt} / \mathrm{C}(75.6 \mu \mathrm{A})$ (Figure 3a). In the case of the acidic medium, $\mathrm{Fe}-\mathrm{N} / \mathrm{Fe}_{3} \mathrm{C} / \mathrm{Fe} / \mathrm{C}-800$ also showed a larger peak current of $151.0 \mu \mathrm{A}$ than that of $\mathrm{Pt} / \mathrm{C}(115.2 \mu \mathrm{A})$ (Figure 3c). The higher capacitance currents of $\mathrm{Fe}-\mathrm{N} / \mathrm{Fe}_{3} \mathrm{C} / \mathrm{Fe} / \mathrm{C}-800$ in both alkaline and acidic media may be caused by a favorable $\mathrm{O}_{2}$ transport within the layer of the catalyst [35]. The catalytic activities for ORR of $\mathrm{Fe}-\mathrm{N} / \mathrm{Fe}_{3} \mathrm{C} / \mathrm{Fe} / \mathrm{C}-800$ and $\mathrm{Pt} / \mathrm{C}$ catalysts were also studied by rotating disk electrode (RDE) in Figure 3b,d. The onset potential for the $\mathrm{Fe}-\mathrm{N} / \mathrm{Fe}_{3} \mathrm{C} / \mathrm{Fe} / \mathrm{C}-800$ in alkaline conditions $(1.00 \mathrm{~V})$ 
was very similar to that for Pt/C. The half-wave potentials $\left(\mathrm{E}_{1 / 2}\right)$ for $\mathrm{Fe}-\mathrm{N} / \mathrm{Fe}_{3} \mathrm{C} / \mathrm{Fe} / \mathrm{C}-800$ and $\mathrm{Pt} / \mathrm{C}$ were 0.82 and $0.85 \mathrm{~V}$, respectively (Figure $3 \mathrm{~b}$ ). Although $\mathrm{E}_{1 / 2}(0.62 \mathrm{~V})$ of $\mathrm{Fe}-\mathrm{N} / \mathrm{Fe}_{3} \mathrm{C} / \mathrm{Fe} / \mathrm{C}-800$ was more negatively shifted relative to $\mathrm{Pt} / \mathrm{C}$ in acidic media, there were insignificant differences observed from their onset potentials (Figure $3 \mathrm{~d}$ ). In addition, the diffusion limited current densities $\left(j_{\mathrm{L}}\right)$ of $\mathrm{Fe}-\mathrm{N} / \mathrm{Fe}_{3} \mathrm{C} / \mathrm{Fe} / \mathrm{C}-800$ were 6.23 and $5.48 \mathrm{~mA} \mathrm{~cm}^{-2}$ at a rotating speed of $1600 \mathrm{rpm}$ in $0.1 \mathrm{M} \mathrm{KOH}$ and $0.1 \mathrm{M} \mathrm{HClO}_{4}$, respectively, which were close to the theoretical limiting current density of $6.0 \mathrm{~mA} \mathrm{~cm}{ }^{-2}$. Figure 4a exhibits the Tafel plots of Fe-N/Fe $3 \mathrm{C} / \mathrm{Fe} / \mathrm{C}-800$ and $\mathrm{Pt} / \mathrm{C}$ catalysts in $0.1 \mathrm{M} \mathrm{KOH}$, derived from Figure 3b. Fe-N $/ \mathrm{Fe}_{3} \mathrm{C} / \mathrm{Fe} / \mathrm{C}-800$ showed a Tafel slope of $45 \mathrm{mV} /$ dec that was similar to that of $\mathrm{Pt} / \mathrm{C}(40 \mathrm{mV} / \mathrm{dec})$, indicating a good kinetic process for ORR. The Tafel plots of $\mathrm{Fe}-\mathrm{N} / \mathrm{Fe}_{3} \mathrm{C} / \mathrm{Fe} / \mathrm{C}-800$ and $\mathrm{Pt} / \mathrm{C}$ catalysts in $0.1 \mathrm{M} \mathrm{HClO}_{4}$ are shown in Figure $4 \mathrm{~b}$, deduced from Figure $3 \mathrm{~d}$. The former had a Tafel slope of $152 \mathrm{mV} / \mathrm{dec}$ and the later owned a Tafel slope of $81 \mathrm{mV} /$ dec.
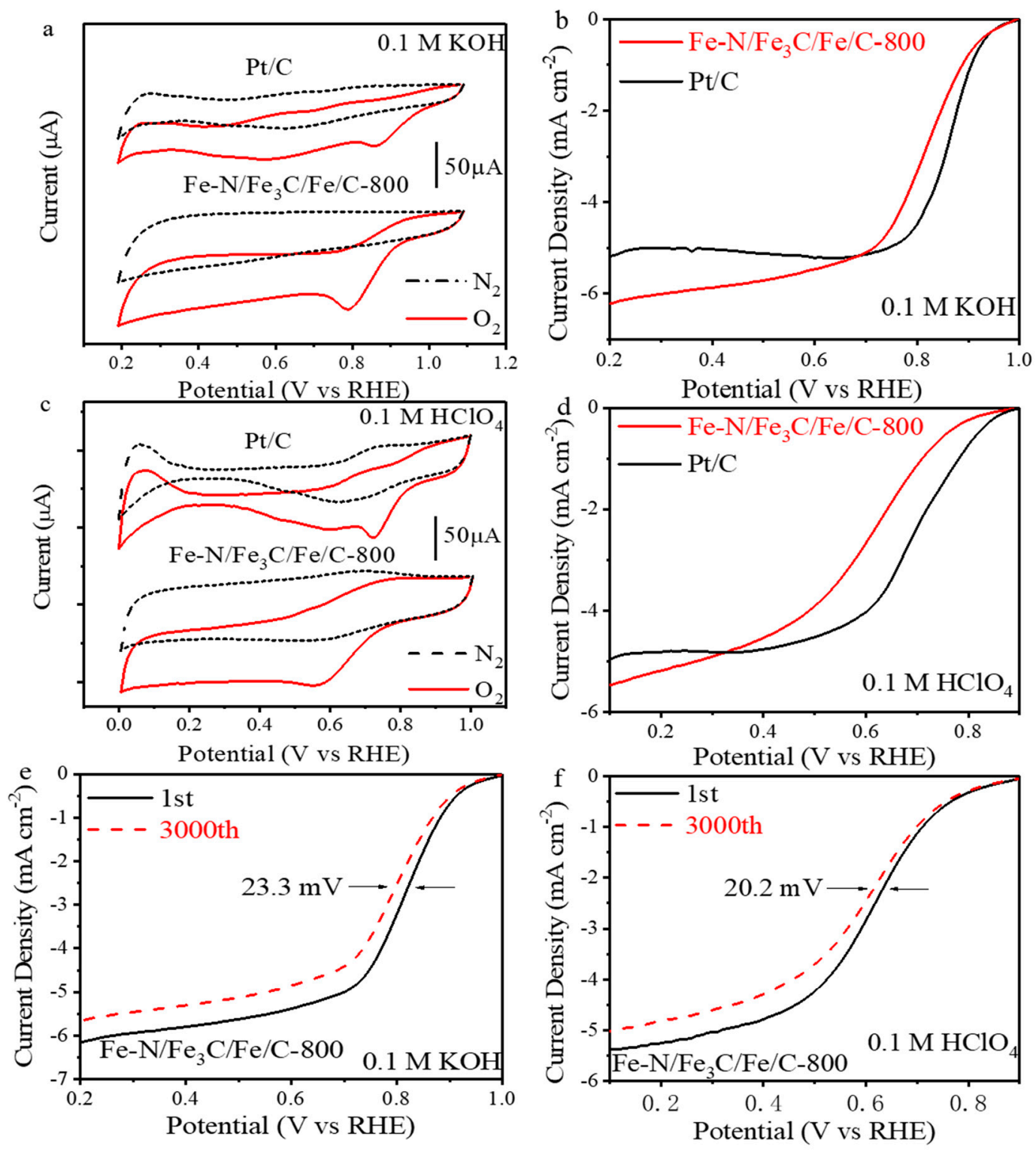

Figure 3. (a) Cyclic voltammograms of $\mathrm{Pt} / \mathrm{C}$ and $\mathrm{Fe}-\mathrm{N} / \mathrm{Fe}_{3} \mathrm{C} / \mathrm{Fe} / \mathrm{C}-800$ in $0.1 \mathrm{M} \mathrm{KOH}$; (b) Oxygen reduction reaction (ORR) polarization curves of $\mathrm{Pt} / \mathrm{C}$ and $\mathrm{Fe}-\mathrm{N} / \mathrm{Fe}_{3} \mathrm{C} / \mathrm{Fe} / \mathrm{C}-800$ in $0.1 \mathrm{M} \mathrm{KOH}$; (c) cyclic voltammograms of $\mathrm{Pt} / \mathrm{C}$ and $\mathrm{Fe}-\mathrm{N} / \mathrm{Fe}_{3} \mathrm{C} / \mathrm{Fe} / \mathrm{C}-800$ in $0.1 \mathrm{M} \mathrm{HClO}_{4}$; (d) ORR polarization curves of $\mathrm{Pt} / \mathrm{C}$ and $\mathrm{Fe}-\mathrm{N} / \mathrm{Fe}_{3} \mathrm{C} / \mathrm{Fe} / \mathrm{C}-800$ in $0.1 \mathrm{M} \mathrm{HClO}_{4} ;(\mathbf{e}, \mathbf{f})$ endurance test of $\mathrm{Fe}-\mathrm{N} / \mathrm{Fe}_{3} \mathrm{C} / \mathrm{Fe} / \mathrm{C}-800$ for 3000 cycles in $\mathrm{O}_{2}$-saturated $\mathrm{KOH}$ and $\mathrm{HClO}_{4}(0.1 \mathrm{M})$ (Scanning rate: $10 \mathrm{mV} / \mathrm{s}$, rotating). 

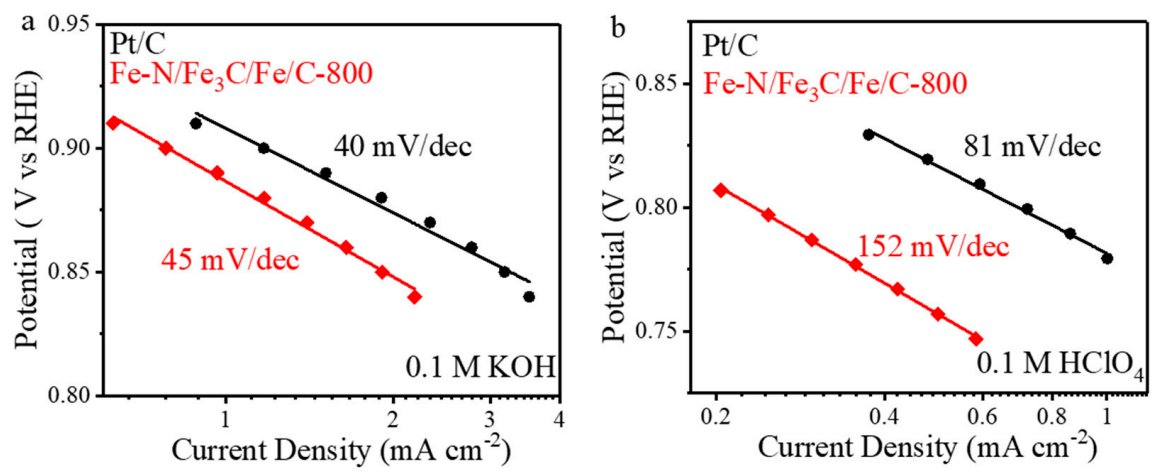

Figure 4. The Tafel plots of $\mathrm{Fe}-\mathrm{N} / \mathrm{Fe}_{3} \mathrm{C} / \mathrm{Fe} / \mathrm{C}-800$ and Pt/C catalysts (a) in $0.1 \mathrm{M} \mathrm{KOH}$ and (b) in 0.1 $\mathrm{M} \mathrm{HClO}_{4}$.

Because of the complicated structure of $\mathrm{Fe}-\mathrm{N} / \mathrm{Fe}_{3} \mathrm{C} / \mathrm{Fe} / \mathrm{C}-800$, it is difficult to tell what kinds of iron species ( $\mathrm{Fe}-\mathrm{N}_{x}, \mathrm{Fe}_{3} \mathrm{C}$ and Fe particles) serve as the major active sites. N-doped carbon was previously proposed as the major active sites in some publications [36-38]. To explore the role of $\mathrm{N}$-doped carbon, we carried out a control experiment which was researched on the pure tri (dipyrido [3,2-a:2 $2^{\prime}, 3^{\prime}$-c] phenazinyl) phenylene without $\mathrm{FeSO}_{4}$. The resulting product was labelled as Ligand-800, which exhibited a worse ORR catalytic performance than that of $\mathrm{Fe}-\mathrm{N} / \mathrm{Fe}_{3} \mathrm{C} / \mathrm{Fe} / \mathrm{C}-800$, especially in acidic conditions (Figure S2b). The role of S-doping was also studied by the S-doped ligand (S-ligand-800), which was prepared by pyrolyzing the tri (dipyrido [3,2-a:2', $3^{\prime}$-c] phenazinyl) phenylene and $\mathrm{ZnSO}_{4}$. The S-ligand-800 showed a better activity than Ligand-800 in both alkaline and acidic media, indicating S-doping improved the catalytic activity of Ligand-800. It might be because the addition of $\mathrm{N}$ into carbon support could increase the electronic density near the Fermi level, facilitate the transfer of electrons between the electronic bands of $\mathrm{C}$ and $\mathrm{O}_{2} \sigma^{*}$ antibonding orbitals, and further improve the electrocatalytic efficiency. In particular, $\mathrm{S}$ with the approximate electronegativity to carbon has also been introduced into carbon materials as a dopant [39-41]. The two control experiments indicate that addition of Fe species into the ligand significantly enhances the catalytic activity, and pristine $\mathrm{N}$-doping and S-doping are insignificant for improving ORR activities. Although $\mathrm{Fe}_{3} \mathrm{C}$ and Fe nanoparticles are unstable in acidic media, carbon embedded $\mathrm{Fe}_{3} \mathrm{C}$ and $\mathrm{Fe}$ nanoparticles for ORR were recently reported to be catalytically active and durable in an acidic electrolyte [42,43]. On a basis of these analyses, we concluded that all of $\mathrm{Fe}$ species $\left(\mathrm{Fe}_{3} \mathrm{C}\right.$, Fe nanoparticles and $\left.\mathrm{Fe}-\mathrm{N}_{x}\right)$ may be capable of making major contributions to catalytic activities, independently or synergistically. The ORR polarization curves at different pyrolyzing temperatures were shown in Figures S2c,d. The best catalyst was obtained at the optimized temperature $\left(800^{\circ} \mathrm{C}\right)$. The LSV measurements proceeded after 3000 cycles exhibited a negative shift of $E_{1 / 2}$ of 23.3 and $20.2 \mathrm{mV}$ in alkaline and acidic media (Figure $3 \mathrm{e}, \mathrm{f})$, respectively, which indicated an excellent stability. The decreases in $E_{1 / 2}$ and $j_{\mathrm{L}}$ of $\mathrm{Fe}-\mathrm{N} / \mathrm{Fe}_{3} \mathrm{C} / \mathrm{Fe} / \mathrm{C}-800$ were caused by the oxidation of carbon support and active sites.

The LSV curves of $\mathrm{Fe}-\mathrm{N} / \mathrm{Fe}_{3} \mathrm{C} / \mathrm{Fe} / \mathrm{C}-800$ at different rotating rates were recorded in Figure $5 \mathrm{a}, \mathrm{b}$. The corresponding Koutecky-Levich (K-L) plots were shown in insets of Figure 5a,b. It was reported that relationship can typically be expressed as a function between the inverse current and the inverse square root of the rotation rate with the change of potentials [44-47]. The average electron-transfer numbers (n) were calculated to be 3.94 and 3.92 for the acidic and alkaline electrolytes, respectively, indicating the ORRs for $\mathrm{Fe}-\mathrm{N} / \mathrm{Fe}_{3} \mathrm{C} / \mathrm{Fe} / \mathrm{C}-800$ were four-electron process in both electrolytes. The disk and ring current measurements at $1600 \mathrm{rpm}$ in $0.1 \mathrm{M} \mathrm{KOH}$ and $0.1 \mathrm{M} \mathrm{HClO}_{4}$ were shown in Figure S2a,b, respectively. Figure S2c shows that the peroxide species yield was less than $12 \%$, and the average electron transfer number was approximately 3.93 in an alkaline solution. For an acidic electrolyte, the peroxide species yield was less than $2 \%$, and the average electron transfer number was 
calculated to be 3.92. These results were consistent with the electron-transfer number, according to the Koutecky-Levich plots.
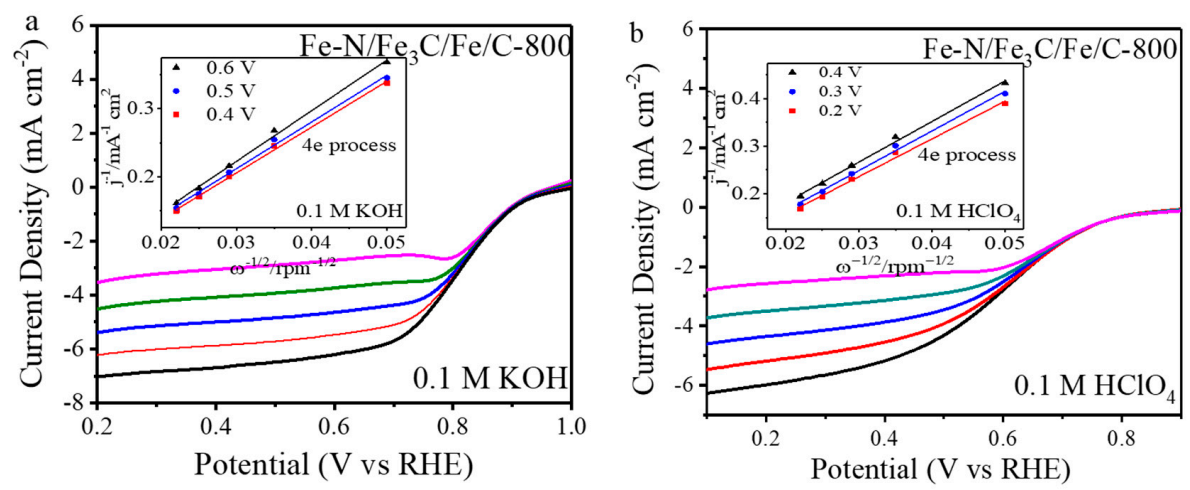

Figure 5. (a) ORR polarization curves of $\mathrm{Fe}-\mathrm{N} / \mathrm{Fe}_{3} \mathrm{C} / \mathrm{Fe} / \mathrm{C}-800$ at different rotating rates and $\mathrm{K}-\mathrm{L}$ plots (inset) in $0.1 \mathrm{M} \mathrm{KOH}$; (b) ORR polarization curves of $\mathrm{Fe}-\mathrm{N} / \mathrm{Fe}_{3} \mathrm{C} / \mathrm{Fe} / \mathrm{C}-800$ at different rotating rates and $\mathrm{K}-\mathrm{L}$ plots (inset) in $0.1 \mathrm{M} \mathrm{HClO}_{4}$.

Notably, our catalyst exhibited excellent tolerance toward methanol relative to $\mathrm{Pt} / \mathrm{C}$ in both alkaline and acidic media. The $\mathrm{CV}$ curves for $\mathrm{Fe}-\mathrm{N} / \mathrm{Fe}_{3} \mathrm{C} / \mathrm{Fe} / \mathrm{C}-800$ had no insignificant changes taken in methanol and without methanol (Figure $6 \mathrm{a}, \mathrm{b}$ ). In the case of $\mathrm{Pt} / \mathrm{C}$, the methanol electro-oxidation hinders the ORR process; the obvious methanol oxidation peaks were observed (Figure $6 c, d$ ). These results suggest that our catalyst is a better choice relative to $\mathrm{Pt} / \mathrm{C}$ for ORR in the application of direct methanol fuel cells.
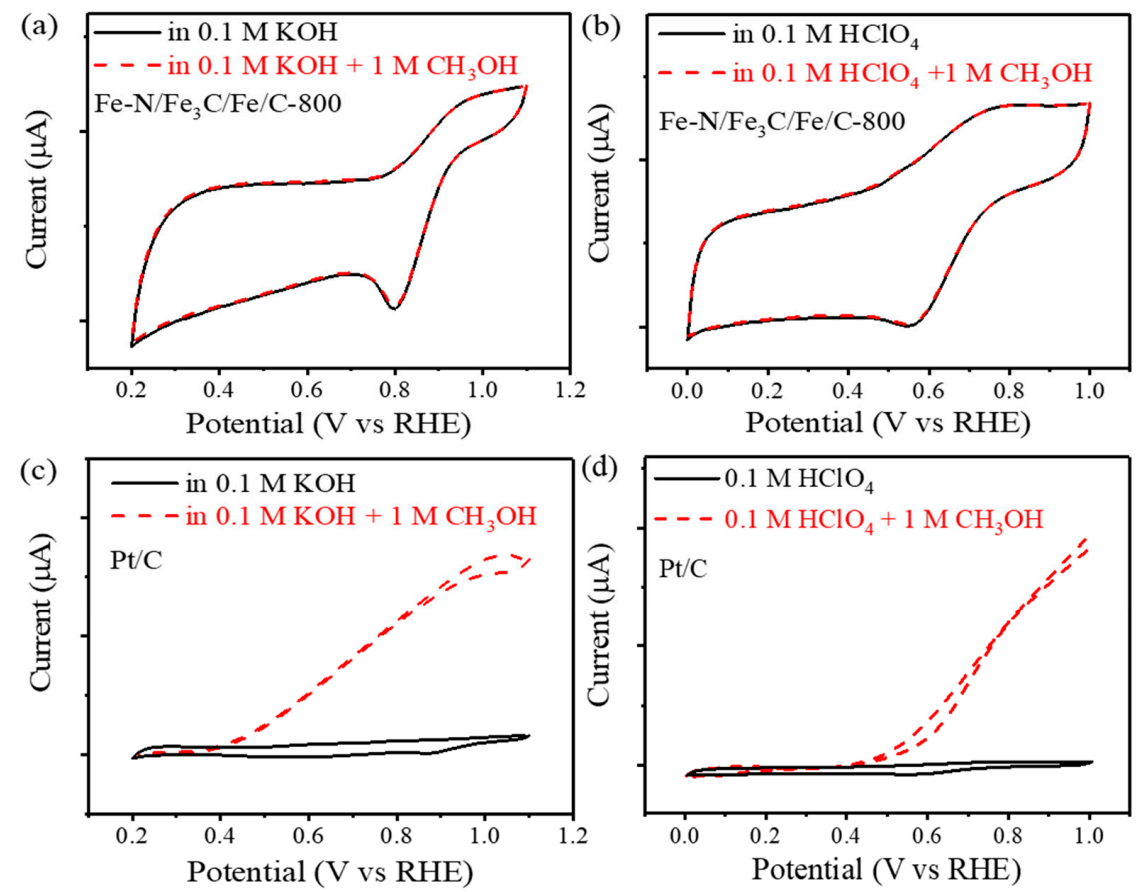

Figure 6. (a) Cyclic voltammograms of $\mathrm{Fe}-\mathrm{N} / \mathrm{Fe}_{3} \mathrm{C} / \mathrm{Fe} / \mathrm{C}-800$ before and after adding $1 \mathrm{M} \mathrm{CH} \mathrm{OH}_{3} \mathrm{O}$ $\mathrm{O}_{2}$-saturated $0.1 \mathrm{M} \mathrm{KOH}$; (b) cyclic voltammograms of $\mathrm{Fe}-\mathrm{N} / \mathrm{Fe}_{3} \mathrm{C} / \mathrm{Fe} / \mathrm{C}-800$ before and after adding $1 \mathrm{M} \mathrm{CH}_{3} \mathrm{OH}$ in $\mathrm{O}_{2}$-saturated $0.1 \mathrm{M} \mathrm{HClO}_{4}$; (c) cyclic voltammograms of $\mathrm{Pt} / \mathrm{C}$ before and after adding $1 \mathrm{M} \mathrm{CH}_{3} \mathrm{OH}$ in $\mathrm{O}_{2}$-saturated $0.1 \mathrm{M} \mathrm{KOH} ;(\mathbf{d})$ cyclic voltammograms of $\mathrm{Pt} / \mathrm{C}$ before and after adding $1 \mathrm{M} \mathrm{CH}_{3} \mathrm{OH}$ in $\mathrm{O}_{2}$-saturated $0.1 \mathrm{M} \mathrm{HClO}_{4}$. 
We also evaluated the performance of zinc-air batteries using $\mathrm{Fe}-\mathrm{N} / \mathrm{Fe}_{3} \mathrm{C} / \mathrm{Fe} / \mathrm{C}-800$-based air cathodes. The specific capacity of zinc-air batteries was obtained in a $6 \mathrm{M} \mathrm{KOH}$ electrolyte under ambient air at a current density of $20 \mathrm{~mA} \cdot \mathrm{cm}^{-2}$ (Figure 7a). The $\mathrm{Fe}-\mathrm{N} / \mathrm{Fe}_{3} \mathrm{C} / \mathrm{Fe} / \mathrm{C}-800$ showed a specific capacity of $700 \mathrm{mAh} \cdot \mathrm{g}^{-1}$ that is comparable to $\mathrm{Pt} / \mathrm{C}$-based battery. Figure $7 \mathrm{~b}$ shows voltages and power density as a function of current density for $\mathrm{Fe}-\mathrm{N} / \mathrm{Fe}_{3} \mathrm{C} / \mathrm{Fe} / \mathrm{C}-800$ and $\mathrm{Pt} / \mathrm{C}$. The maximum power density was approximately $110 \mathrm{~mW} \mathrm{~cm}^{-2}$. Both of them exhibited very similar electrochemical performance. The scarcity and high cost of Pt-based materials limited their scale application for zinc batteries, based on this consideration. $\mathrm{Fe}-\mathrm{N} / \mathrm{Fe}_{3} \mathrm{C} / \mathrm{Fe} / \mathrm{C}-800$ could be regarded as the promising replacement of noble-metal-based catalysts for zinc batteries.
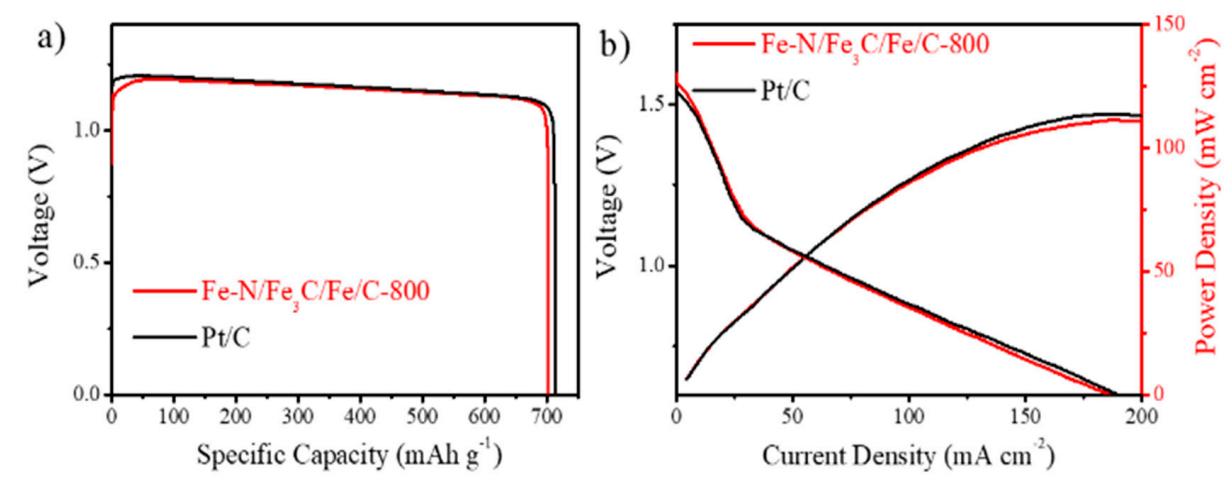

Figure 7. Zinc-air batteries performance. (a) Specific capacity under constant discharge current density $\left(20 \mathrm{~mA} \mathrm{~cm}^{-2}\right)$ using the $\mathrm{Fe}-\mathrm{N} / \mathrm{Fe}_{3} \mathrm{C} / \mathrm{Fe} / \mathrm{C}-800$ and $\mathrm{Pt} / \mathrm{C}$-based air cathodes. (b) Voltage-current curves and power density of two-electrode zinc-air batteries of the $\mathrm{Fe}-\mathrm{N} / \mathrm{Fe}_{3} \mathrm{C} / \mathrm{Fe} / \mathrm{C}-800$ and $\mathrm{Pt} / \mathrm{C}$-based air cathodes in $6 \mathrm{M} \mathrm{KOH}$.

\section{Materials and Methods}

\subsection{Chemicals}

The 2, 3, 6, 7, 10, 11-hexabromo-triphenylene was purchased from TCI (98\%, Japan). Tris (dibenzylideneacetone) dipalladium (0) (97\%), rac-BINAP (97\%), benzophenone imine (95\%) and 1, 10-Phenanthroline-5, 6-dione (97\%) were purchased from Aldrich (USA).

\subsection{Synthesis of Tri (dipyrido[3,2-a:2', $\left.3^{\prime}-c\right]$ phenazinyl) Phenylene}

Triphenylene-cored hexamine was prepared by following a previously reported procedure [48]. In a typical synthesis, a suspension of triphenylene-cored hexamine $(0.134 \mathrm{~g}, 0.24 \mathrm{mmol})$ in ethanol $(6.0 \mathrm{~mL})$ was added into Et3N $(0.218 \mathrm{~g}, 2.16 \mathrm{mmol})$. The solution was stirred with a magnetic heated stirrer for $10 \mathrm{~min}$. Then, 1, 10-Phenanthroline-5, 6-dione $(0.230 \mathrm{~g}, 1.08 \mathrm{mmol})$ in ethanol $(6.0 \mathrm{~mL})$ was added into the mentioned solution. The mixture was stirred at a reflux temperature for $12 \mathrm{~h}$. The product was sonicated and centrifuged for several times. The resulted precipitate was dried at $80{ }^{\circ} \mathrm{C}$ overnight under vacuum to give $0.2 \mathrm{~g}$ nitrogen-rich carbon ligand tri (dipyrido[3,2-a:2', $\left.3^{\prime}-\mathrm{c}\right]$ phenazinyl) phenylene. The calculated C, $\mathrm{H}$ and $\mathrm{N}$ elemental analysis showed $77.13 \% \mathrm{C}, 2.88 \% \mathrm{H}$ and $19.99 \% \mathrm{~N}$, while the experimental elemental analysis exhibited $75.84 \% \mathrm{C}, 3.12 \% \mathrm{H}$ and $18.83 \% \mathrm{~N}$.

\subsection{Synthesis of Catalysts}

Tri (dipyrido[3,2-a:2', $\left.3^{\prime}-\mathrm{c}\right]$ phenazinyl) phenylene $(0.2 \mathrm{~g})$ was added into $40 \mathrm{~mL}$ DMF, and a homogenous solution was formed after sonication. Then, $\mathrm{FeSO}_{4} \cdot 7 \mathrm{H}_{2} \mathrm{O}(0.38 \mathrm{~g}, 1.08 \mathrm{mmol})$ was added into the mentioned solution under vigorous stirring conditions. The resulted solution was heated at $110^{\circ} \mathrm{C}$ overnight. Finally, the mixture was transferred to a $50 \mathrm{~mL}$ Teflon-lined stainless autoclave and heated at $160{ }^{\circ} \mathrm{C}$ for $12 \mathrm{~h}$. The brown solid was collected via centrifugation, washed with DMF and 
ethanol more than once and dried overnight under vacuum at $80^{\circ} \mathrm{C}$. Finally, the dried precursor was heated to $700,750,800$, and $850^{\circ} \mathrm{C}$ for $1.5 \mathrm{~h}$ at a heating rate of $5{ }^{\circ} \mathrm{C} / \mathrm{min}$. The pyrolyzed product was ultrasonically leached in $6 \mathrm{M}$ hydrochloride acid $(\mathrm{HCl})$ for $8 \mathrm{~h}$. The leached sample was washed to be neutralized with deionized water, and dried overnight in a vacuum drying oven at $80^{\circ} \mathrm{C}$.

\subsection{Characterization of Catalysts}

X-ray diffraction (XRD, D/Max2000, Rigaku, Japan) was tested with $\mathrm{Cu}-\mathrm{K} \alpha$ radiation. An Escalab instrument (Escalab 250 xi, Thermo Scientific, Loughborough, UK) was used to measure X-ray photoelectron spectroscopy (XPS), and provided a base pressure of $5 \times 10^{-9}$ Torr by a monochromatic $\mathrm{Al} \mathrm{K} \alpha$ radiation $(1486.6 \mathrm{eV})$. The scanning electron microscope (S-4800, Hitachi, Tokyo, Japan) was used to characterize morphology with an operating voltage of $10 \mathrm{kV}$, and HRTEM (JEM-2100F, JEOL, Tokyo, Japan) was characterized at a voltage of $200 \mathrm{kV}$. Co K-edge X-ray absorption spectra, X-ray absorption near edge structure (XANES) spectra and extended X-ray absorption fine structure (EXAFS) spectra were analyzed on the BL10C beam line at the Pohang Light Source (PLS-II) in Korea with a ring current of $200 \mathrm{~mA}$ at $3.0 \mathrm{G} \mathrm{eV}$.

\subsection{Electrochemical Measurement}

$\mathrm{CV}$ measurements of the catalysts were determined using a glassy carbon (4 $\mathrm{mm}$ in diameter) electrode. The measurements were tested with a standard three-electrode electrochemical system filled with $0.1 \mathrm{M} \mathrm{KOH}$ or $0.1 \mathrm{M} \mathrm{HClO}_{4}$ electrolytes. A Pt wire was served as a counter electrode. $\mathrm{The} \mathrm{Hg} / \mathrm{HgO}$ and $\mathrm{Ag} / \mathrm{AgCl}$ were used as reference electrodes in alkaline and acidic media, respectively. Before the electrochemical measurements, high-purity $\mathrm{O}_{2}$ gas was filled with the solution for approximately $20 \mathrm{~min}$ and kept for the whole testing process. Sixty microliter of Nafion solution $(5.0 \mathrm{wt} \%)$ containing a $3.0 \mathrm{mg}$ catalyst was adequately dispersed into the solution of ethanol $(0.35 \mathrm{~mL})$ and deionized water $(0.15 \mathrm{~mL})$. Then, the solution was ultrasonicated to form homogeneous ink. Afterwards, $5.0 \mu \mathrm{L}$ of the obtained catalyst ink $\left(0.21 \mathrm{mg} \mathrm{cm}^{-2}\right)$ was dropped onto the electrode surface for ORR. The loading of Pt/C (20\% Pt on Vulcan XC-72, Premetek Co) was 1.5 times the catalysts' loading $\left(0.32 \mathrm{mg} \mathrm{cm}^{-2}\right)$. Measurements were also proceeded in $\mathrm{N}_{2}$ flowing through the electrochemical cell as the control experiments. Linear sweep voltammetry (LSV) measurements of the samples were characterized by using a rotating disk electrode (RDE). The scan rate of the working electrode was $10 \mathrm{mV} \cdot \mathrm{s}^{-1}$ and varying rotating speeds from 400 to $2000 \mathrm{rpm}$ after 10 cycles were performed.

Zinc-air batteries: The air cathodes were made by coating a mixture of the activated charcoal and PTFE (the weight ratio $=7: 3$ ) on the nickel foam, and each air cathode was fixed to be $\sim 500 \mu \mathrm{m}$ by an electrode pressing machine. Sixty microliter of Nafion solution (5.0 wt \%) containing $3.0 \mathrm{mg}$ catalyst were dispersed in $0.35 \mathrm{~mL}$ of ethanol and $0.15 \mathrm{~mL}$ of deionized water to form homogeneous ink. The $250 \mu \mathrm{L}$ ink was carefully dropped onto the above air cathode and kept it in a vacuum container for $30 \mathrm{~min}$, followed by a mildly pressing procedure. The prepared-catalyst-air cathodes were used to assemble primary and rechargeable zinc-air batteries. A zinc plate was used as the anode that was separated by a nylon polymer membrane with the cathode, and $6 \mathrm{M} \mathrm{KOH}$ electrolyte was filled between the cathode and anode. The nickel foam was used as a current collector [49].

\section{Conclusions}

In summary, we synthesized an electrocatalyst composed of $\mathrm{Fe}-\mathrm{N} / \mathrm{Fe}_{3} \mathrm{C} / \mathrm{Fe} / \mathrm{C}-800$ by template-free pyrolysis of a tri (dipyrido $\left[3,2-\mathrm{a}: 2^{\prime}, 3^{\prime}-\mathrm{c}\right]$ phenazinyl) phenylene-based metal organic framework. The catalyst demonstrated high activity and good durability for ORR in both alkaline and acidic media. The catalyst also exhibited strong methanol tolerance that makes it potential in practical PEMFCs. Notably, $\mathrm{Fe}-\mathrm{N} / \mathrm{Fe}_{3} \mathrm{C} / \mathrm{Fe} / \mathrm{C}-800$ showed as a potential alternative to $\mathrm{Pt} / \mathrm{C}$ in zinc-air batteries. Such a template-free approach toward porous carbons-supported nanocomposites of nitrogen-coordinated and carbon-embedded metal opens up a new avenue for preparing non-precious metal catalysts for applications in energy conversion and storage devices. 
Supplementary Materials: The following are available online at http:/ /www.mdpi.com/2073-4344/8/6/243/s1. Figure S1: XPS spectra of C 1s (a) and S 2p (b) for Fe-N/Fe3C/Fe/C-800, Figure S2: Linear sweeping voltammograms for oxygen reduction reaction at $1600 \mathrm{rpm}$. (a) Ligand-800, S-Ligand-800, and Fe-N/Fe $3 \mathrm{C} / \mathrm{Fe} / \mathrm{C}-800 \mathrm{in} 0.1 \mathrm{M} \mathrm{KOH}$. (b) Ligand-800, S-Ligand-800, and $\mathrm{Fe}-\mathrm{N} / \mathrm{Fe}_{3} \mathrm{C} / \mathrm{Fe} / \mathrm{C}-800$ in $0.1 \mathrm{M} \mathrm{HClO}_{4}$. (c) $\mathrm{Fe}-\mathrm{N} / \mathrm{Fe}_{3} \mathrm{C} / \mathrm{Fe} / \mathrm{C}$ catalysts with different pyrolyzing temperatures in $0.1 \mathrm{M} \mathrm{KOH}$. (d) $\mathrm{Fe}-\mathrm{N} / \mathrm{Fe}_{3} \mathrm{C} / \mathrm{Fe} / \mathrm{C}$ catalysts with different pyrolyzing temperatures in $0.1 \mathrm{M} \mathrm{HClO}_{4}$, Figure S3: (a), (b) Rotating ring-disk electrode voltammogram of $\mathrm{Fe}-\mathrm{N} / \mathrm{Fe}_{3} \mathrm{C} / \mathrm{Fe} / \mathrm{C}-800$ in $\mathrm{O}_{2}$-saturated $0.1 \mathrm{M} \mathrm{KOH}$ and $0.1 \mathrm{M} \mathrm{HClO}_{4}$ at $1600 \mathrm{rpm}$, respectively. (c) The electron transfer number (n) of $\mathrm{Fe}-\mathrm{N} / \mathrm{Fe}_{3} \mathrm{C} / \mathrm{Fe} / \mathrm{C}-800$ at different potentials and percentage of peroxide with respect to the total oxygen reduction products in $0.1 \mathrm{M} \mathrm{KOH}$ and $0.1 \mathrm{M} \mathrm{HClO}_{4}$, respectively.

Author Contributions: Data curation, X.S.; investigation, J.Z.; methodology, P.L.; project administration, X.L.; software, Z.W.; Writing of the original draft, S.W.

Acknowledgments: This work was supported by the Natural Science Foundation of Shandong Province of China (ZR2017MB054), the Key Research and Development Program of Shandong Province (2018GGX104001), Doctoral Fund of QUST (010022873, 0100229001) and Taishan Scholar Program of Shandong Province in China (tS201712045).

Conflicts of Interest: The authors declare no conflict of interest.

\section{References}

1. Su, D.S.; Sun, G.Q. Nonprecious-Metal Catalysts for Low-Cost Fuel Cells. Angew. Chem. Int. Ed. 2011, 50, 11570-11572. [CrossRef] [PubMed]

2. Wu, G.; More, K.L.; Johnston, C.M.; Zelenay, P. High-Performance Electrocatalysts for Oxygen Reduction Derived from Polyaniline, Iron, and Cobalt. Science 2011, 332, 443-447. [CrossRef] [PubMed]

3. Tian, J.; Morozan, A.; Sougrati, M.T.; Lefevre, M.; Chenitz, R.; Dodelet, J.P.; Jones, D.; Jaouen, F. Optimized Synthesis of Fe/N/C Cathode Catalysts for PEM Fuel Cells: A Matter of Iron-Ligand Coordination Strength. Angew. Chem. Int. Ed. 2013, 52, 6867-6870. [CrossRef] [PubMed]

4. Wang, Z.; Liu, H.; Ge, R.; Ren, X.; Ren, J.; Yang, D.; Zhang, L.; Sun, X. Phosphorus-Doped $\mathrm{Co}_{3} \mathrm{O}_{4} \mathrm{Nanowire}$ Array: A Highly Efficient Bifunctional Electrocatalyst for Overall Water Splitting. ACS Catal. 2018, 8, 2236-2241. [CrossRef]

5. Lu, Y.; Jiang, Y.; Gao, X.; Wang, X.; Chen, W. Strongly coupled Pd nanotetrahedron/tungsten oxide nanosheet hybrids with enhanced catalytic activity and stability as oxygen reduction electrocatalysts. J. Am. Chem. Soc. 2014, 136, 11687-11697. [CrossRef] [PubMed]

6. Ma, S.; Goenaga, G.A.; Call, A.V.; Liu, D.J. Cobalt imidazolate framework as precursor for oxygen reduction reaction electrocatalysts. Chem.-A Eur. J. 2011, 17, 2063-2067. [CrossRef] [PubMed]

7. Wang, Y.C.; Lai, Y.J.; Song, L.; Zhou, Z.Y.; Liu, J.G.; Wang, Q.; Yang, X.D.; Chen, C.; Shi, W.; Zheng, Y.P.; et al. S-Doping of an Fe/N/C ORR Catalyst for Polymer Electrolyte Membrane Fuel Cells with High Power Density. Angew. Chem. Int. Ed. 2015, 54, 9907-9910. [CrossRef] [PubMed]

8. Zhu, Y.S.; Zhang, B.S.; Liu, X.; Wang, D.W.; Su, D.S. Unravelling the Structure of Electrocatalytically Active Fe-N Complexes in Carbon for the Oxygen Reduction Reaction. Angew. Chem. Int. Ed. 2014, 53, 10673-10677. [CrossRef] [PubMed]

9. Lin, L.; Zhu, Q.; Xu, A.W. Noble-Metal-Free Fe-N/C Catalyst for Highly Efficient Oxygen Reduction Reaction under Both Alkaline and Acidic Conditions. J. Am. Chem. Soc. 2014, 136, 11027-11033. [CrossRef] [PubMed]

10. Lefevre, M.; Proietti, E.; Jaouen, F.; Dodelet, J.P. Iron-Based Catalysts with Improved Oxygen Reduction Activity in Polymer Electrolyte Fuel Cells. Science 2009, 324, 71-74. [CrossRef] [PubMed]

11. Zitolo, A.; Goellner, V.; Armel, V.; Sougrati, M.T.; Mineva, T.; Stievano, L.; Fonda, E.; Jaouen, F. Identification of catalytic sites for oxygen reduction in iron- and nitrogen-doped graphene materials. Nat. Mater. 2015, 14, 937-942. [CrossRef] [PubMed]

12. Qu, L.T.; Liu, Y.; Baek, J.B.; Dai, L.M. Nitrogen-Doped Graphene as Efficient Metal-Free Electrocatalyst for Oxygen Reduction in Fuel Cells. ACS Nano 2010, 4, 1321-1326. [CrossRef] [PubMed]

13. Liu, R.L.; Wu, D.Q.; Feng, X.L.; Mullen, K. Nitrogen-Doped Ordered Mesoporous Graphitic Arrays with High Electrocatalytic Activity for Oxygen Reduction. Angew. Chem. Int. Ed. 2010, 49, 2565-2569. [CrossRef] [PubMed]

14. Maldonado, S.; Stevenson, K.J. Influence of nitrogen doping on oxygen reduction electrocatalysis at carbon nanofiber electrodes. J. Phys. Chem. B 2005, 109, 4707-4716. [CrossRef] [PubMed] 
15. Matter, P.H.; Zhang, L.; Ozkan, U.S. The role of nanostructure in nitrogen-containing carbon catalysts for the oxygen reduction reaction. J. Catal. 2006, 239, 83-96. [CrossRef]

16. Gong, K.P.; Du, F.; Xia, Z.H. Nitrogen-Doped Carbon Nanotube Arrays with High Electrocatalytic Activity for Oxygen Reduction. Science 2009, 323, 760-764. [CrossRef] [PubMed]

17. Guo, D.Y.; Zheng, C.; Deng, W.J.; Chen, X.A.; Wei, H.F.; Liu, M.L.; Huang, S.M. Nitrogen-doped porous carbon plates derived from fallen camellia flower for electrochemical energy storage. J. Solid State Electr. 2016, 21, 1165-1174. [CrossRef]

18. Proietti, E.; Jaouen, F.; Lefevre, M.; Larouche, N.; Tian, J.; Herranz, J.; Dodelet, J.P. Iron-based cathode catalyst with enhanced power density in polymer electrolyte membrane fuel cells. Nat. Commun. 2011, 2, 416. [CrossRef] [PubMed]

19. Deng, D.H.; Yu, L.; Chen, X.Q.; Wang, G.X.; Jin, L.; Pan, X.L.; Deng, J.; Sun, G.Q.; Bao, X.H. Iron Encapsulated within Pod-like Carbon Nanotubes for Oxygen Reduction Reaction. Angew. Chem. Int. Ed. 2013, 52, 371-375. [CrossRef] [PubMed]

20. Yang, W.X.; Liu, X.J.; Yue, X.Y.; Jia, J.B.; Guo, S.J. Bamboo-like Carbon Nanotube $/ \mathrm{Fe}_{3} \mathrm{C}$ Nanoparticle Hybrids and Their Highly Efficient Catalysis for Oxygen Reduction. J. Am. Chem. Soc. 2015, 137, 1436-1439. [CrossRef] [PubMed]

21. Arul, N.S.; Han, J.I.; Chen, P.C. Fabrication of $\beta-\mathrm{Ni}(\mathrm{OH})_{2} / / \gamma-\mathrm{Fe}_{2} \mathrm{O}_{3}$ nanostructures for high-performance asymmetric supercapacitors. J. Solid State Electr. 2017, 22, 293-302. [CrossRef]

22. Panomsuwan, G.; Saito, N.; Ishizaki, T. Fe-N-doped carbon-based composite as an efficient and durable electrocatalyst for the oxygen reduction reaction. RSC Adv. 2016, 6, 114553-114559. [CrossRef]

23. Yan, X.; Yu, S.; Tang, Y.; Sun, D.; Xu, L.; Xue, C. Triangular AgAu@Pt core-shell nanoframes with a dendritic Pt shell and enhanced electrocatalytic performance toward the methanol oxidation reaction. Nanoscale 2018, 10, 2231-2235. [CrossRef] [PubMed]

24. Liang, Y.Y.; Schwab, M.G.; Zhi, L.J.; Mugnaioli, E.; Kolb, U.; Feng, X.L.; Mullen, K. Direct Access to Metal or Metal Oxide Nanocrystals Integrated with One-Dimensional Nanoporous Carbons for Electrochemical Energy Storage. J. Am. Chem. Soc. 2010, 132, 15030-15037. [CrossRef] [PubMed]

25. Tang, J.; Liu, J.; Li, C.L.; Li, Y.Q.; Tade, M.O.; Dai, S.; Yamauchi, Y. Synthesis of Nitrogen-Doped Mesoporous Carbon Spheres with Extra-Large Pores through Assembly of Diblock Copolymer Micelles. Angew. Chem. Int. Ed. 2015, 54, 588-593. [CrossRef]

26. Wang, X.Q.; Lee, J.S.; Zhu, Q.; Liu, J.; Wang, Y.; Dai, S. Ammonia-Treated Ordered Mesoporous Carbons as Catalytic Materials for Oxygen Reduction Reaction. Chem. Mater. 2010, 22, 2178-2180. [CrossRef]

27. Jin, H.; Zhang, H.M.; Zhong, H.X.; Zhang, J.L. Nitrogen-doped carbon xerogel: A novel carbon-based electrocatalyst for oxygen reduction reaction in proton exchange membrane (PEM) fuel cells. Energy Environ. Sci. 2011, 4, 3389-3394. [CrossRef]

28. Wu, Z.S.; Chen, L.; Liu, J.Z.; Parvez, K.; Liang, H.W.; Shu, J.; Sachdev, H.; Graf, R.; Feng, X.L.; Mullen, K. High-Performance Electrocatalysts for Oxygen Reduction Derived from Cobalt Porphyrin-Based Conjugated Mesoporous Polymers. Adv Mater. 2014, 26, 1450-1455. [CrossRef] [PubMed]

29. Xu, Z.; Liu, Y.; Zhou, W.; Tade, M.O.; Shao, Z. B-Site Cation-Ordered Double-Perovskite Oxide as an Outstanding Electrode Material for Supercapacitive Energy Storage Based on the Anion Intercalation Mechanism. ACS Appl. Mater. Interfaces 2018, 10, 9415-9423. [CrossRef] [PubMed]

30. Wen, Z.H.; Ci, S.Q.; Zhang, F.; Feng, X.L.; Cui, S.M.; Mao, S.; Luo, S.L.; He, Z.; Chen, J.H. Nitrogen-Enriched Core-Shell Structured $\mathrm{Fe} / \mathrm{Fe}_{3} \mathrm{C}-\mathrm{C}$ Nanorods as Advanced Electrocatalysts for Oxygen Reduction Reaction. Adv. Mater. 2012, 24, 1399-1404. [CrossRef] [PubMed]

31. Li, Q.; Xu, P.; Gao, W.; Ma, S.G.; Zhang, G.Q.; Cao, R.G.; Cho, J.; Wang, H.L.; Wu, G. Graphene/ Graphene-Tube Nanocomposites Templated from Cage-Containing Metal-Organic Frameworks for Oxygen Reduction in $\mathrm{Li}_{2} \mathrm{O}_{2}$ Batteries. Adv. Mater. 2014, 26, 1378-1386. [CrossRef] [PubMed]

32. Li, J.S.; Li, S.L.; Tang, Y.J.; Han, M.; Dai, Z.H.; Bao, J.C.; Lan, Y.Q. Nitrogen-doped Fe/Fe 3 C@graphitic layer/carbon nanotube hybrids derived from MOFs: EFFICIENT bifunctional electrocatalysts for ORR and OER. Chem. Commun. 2015, 51, 2710-2713. [CrossRef] [PubMed]

33. Feng, L.Y.; Chen, X.T.; Cao, Y.; Chen, Y.Z.; Wang, F.; Chen, Y.G.; Liu, Y. Pyridinic and pyrrolic nitrogen-rich ordered mesoporous carbon for efficient oxygen reduction in microbial fuel cells. RSC Adv. 2017, 7, 14669-14677. [CrossRef] 
34. Gupta, A.; Kumar, A.; Waghmare, U.V.; Hegde, M.S. Origin of activation of Lattice Oxygen and Synergistic Interaction in Bimetal-Ionic $\mathrm{Ce}_{0.89} \mathrm{Fe}_{0.1} \mathrm{Pd}_{0.01} \mathrm{O}_{2}$-delta Catalyst. Chem. Mater. 2009, 21, 4880-4891. [CrossRef]

35. Strickland, K.; Elise, M.W.; Jia, Q.Y.; Tylus, U.; Ramaswamy, N.; Liang, W.T.; Sougrati, M.T.; Jaouen, F.; Mukerjee, S. Highly active oxygen reduction non-platinum group metal electrocatalyst without direct metal-nitrogen coordination. Nat. Commun. 2015, 6, 1-8. [CrossRef] [PubMed]

36. Bard, A.J. Inner-Sphere Heterogeneous Electrode Reactions. Electrocatalysis and Photocatalysis: The Challenge. J. Am. Chem. Soc. 2010, 132, 7559-7567. [CrossRef] [PubMed]

37. Kim, J.H.; Sa, Y.J.; Jeong, H.Y.; Joo, S.H. Roles of Fe- $\mathrm{N}_{\mathrm{x}}$ and $\mathrm{Fe}-\mathrm{Fe}_{3} \mathrm{C} @ \mathrm{C}$ Species in Fe-N/C Electrocatalysts for Oxygen Reduction Reaction. ACS Appl. Mater. Interfaces 2017, 9, 9567-9575. [CrossRef] [PubMed]

38. Masa, J.; Xia, W.; Muhler, M.; Schuhmann, W. On the Role of Metals in Nitrogen-Doped Carbon Electrocatalysts for Oxygen Reduction. Angew. Chem. Int. Ed. 2015, 54, 10102-10120. [CrossRef] [PubMed]

39. Liang, J.; Jiao, Y.; Jaroniec, M.; Qiao, S.Z. Sulfur and nitrogen dual-doped mesoporous graphene electrocatalyst for oxygen reduction with synergistically enhanced performance. Angew. Chem. Int. Ed. Engl. 2012, 51, 11496-11500. [CrossRef] [PubMed]

40. Yuan, H.Y.; Hou, Y.; Wen, Z.H.; Guo, X.R.; Chen, J.H.; He, Z. Porous Carbon Nanosheets Codoped with Nitrogen and Sulfur for Oxygen Reduction Reaction in Microbial Fuel Cells. ACS Appl. Mater. Interfaces 2015, 7, 18672-18678. [CrossRef] [PubMed]

41. Wu, M.; Wang, J.; Wu, Z.X.; Xin, H.L.; Wang, D.L. Synergistic enhancement of nitrogen and sulfur co-doped graphene with carbon nanosphere insertion for the electrocatalytic oxygen reduction reaction. J. Mater. Chem. A 2015, 3, 7727-7731. [CrossRef]

42. Jiang, R.Z.; Chu, D. Comparative study of $\mathrm{CoFeN}_{\mathrm{x}} / \mathrm{C}$ catalyst obtained by pyrolysis of hemin and cobalt porphyrin for catalytic oxygen reduction in alkaline and acidic electrolytes. J. Power Sources 2014, 245, 352-361. [CrossRef]

43. Silva, R.; Voiry, D.; Chhowalla, M.; Asefa, T. Efficient Metal-Free Electrocatalysts for Oxygen Reduction: Polyaniline-Derived N- and O-Doped Mesoporous Carbons. J. Am. Chem. Soc. 2013, 135, 7823-7826. [CrossRef] [PubMed]

44. Hu, Y.; Jensen, J.O.; Zhang, W.; Cleemann, L.N.; Xing, W.; Bjerrum, N.J.; Li, Q.F. Hollow Spheres of Iron Carbide Nanoparticles Encased in Graphitic Layers as Oxygen Reduction Catalysts. Angew. Chem. Int. Ed. 2014, 53, 3675-3679. [CrossRef] [PubMed]

45. Lai, Y.Q.; Jiao, Y.F.; Song, J.X.; Zhang, K.; Li, J.; Zhang, Z. Fe/Fe 3 C@graphitic carbon shell embedded in carbon nanotubes derived from Prussian blue as cathodes for $\mathrm{Li}-\mathrm{O}_{2}$ batteries. Mater. Chem. Front. 2018, 2, 376-384. [CrossRef]

46. Wang, S.Y.; Yu, D.S.; Dai, L.M. Polyelectrolyte Functionalized Carbon Nanotubes as Efficient Metal-free Electrocatalysts for Oxygen Reduction. J. Am. Chem. Soc. 2011, 133, 5182-5185. [CrossRef] [PubMed]

47. Wu, Z.X.; Song, M.; Wang, J.; Liu, X. Recent Progress in Nitrogen-Doped Metal-Free Electrocatalysts for Oxygen Reduction Reaction. Catalysts 2018, 8, 196. [CrossRef]

48. Xiang, Z.H.; Xue, Y.H.; Cao, D.P.; Huang, L.; Chen, J.F.; Dai, L.M. Highly Efficient Electrocatalysts for Oxygen Reduction Based on 2D Covalent Organic Polymers Complexed with Non-precious Metals. Angew. Chem. Int. Ed. 2014, 53, 2433-2437. [CrossRef] [PubMed]

49. Chen, L.; Kim, J.; Ishizuka, T.; Honsho, Y.; Saeki, A.; Seki, S.; Ihee, H.; Jiang, D.L. Photoconductive Sheets with Extremely High Carrier Mobility and Conduction Anisotropy from Triphenylene-Fused Metal Trigon Conjugates. J. Am. Chem. Soc. 2009, 131, 7287-7292. [CrossRef] [PubMed]

(C) 2018 by the authors. Licensee MDPI, Basel, Switzerland. This article is an open access article distributed under the terms and conditions of the Creative Commons Attribution (CC BY) license (http://creativecommons.org/licenses/by/4.0/). 